o materiały archiwalne zawierające m.in. zbiór dokumentów osobistych i rodzinnych tego twórcy.

Jak wynika z zamieszczonego w Słowniku „Wstępu” redaktorzy planują w przyszłości nie tylko opublikowanie suplementu, ale także wydanie kolejnego tomu poświęconego tym razem ludziom nauki z tamtych terenów - a zatem pracownikom uczelni wyższych, instytucji naukowych oraz nauczycielom.

Agnieszka Wałega

\title{
Stownik biograficzny nauczycieli Wielkopolski Wschodniej, red. P. Gołdyn, t. I, Konin 2012, ss. 300
}

Losy człowieka wiodą przez szkołę, którą tworzą nauczyciele i uczniowie oraz zachodzące pomiędzy nimi interakcje. Mogą one mieć decydujący wpływ na ich dalszą drogę życiową. Każda jednostka, uczestnicząc w procesie edukacyjnym, spotkała na swojej drodze wielu nauczycieli, którzy mieli własny styl porozumiewania się z uczniami, indywidualne metody, formy oraz środki przekazu wiedzy. Jednakże wraz z upływem lat, absolwenci nie pamiętają swoich „mistrzów”. Chcąc ocalić od zapomnienia ich działalność, na rynku wydawniczym pojawiło się wiele prac biograficznych, przedstawiających życie nauczycieli, uczonych, zasłużonych dla polskiej nauki. Są to publikacje tak w formie słownikowej ${ }^{1}$, jak i w postaci opracowań monograficznych. Jednakże niewiele z nich dotyczy danego terenu czy określonego regionu². Dlatego Słownik biograficzny nauczycieli Wielkopolski Wschodniej uzupełnia dotychczasową wiedzę w tym zakresie. Powstał on dzięki współpracy konińskiego Ośrodka Doskonalenia Nauczycieli z Publicz-

\footnotetext{
${ }^{1}$ Przykładowe słowniki biograficzne to m.in.: A. Gąsiorowski (red.), Historia wychowania: słownik biograficzny, Olsztyn 1994; W. Korzeniowski (red.), Słownik biograficzny historii myśli pedagogicznej, BielskoBiała 2006; Cz. Kupisiewicz i M. Kupisiewicz, Poczet wybitnych nauczycieli, t. I i II, Pułtusk 2006; A. Meissner, Stownik biograficzny twórców oświaty i kultury XIX i XX wieku Polski Poludniowo-Wschodniej, Rzeszów 2011; A. Meissner, W. Szulakiewicz (red.), Stownik biograficzny polskiej historii wychowania: praca zbiorowa, Toruń 2008; H. Tadeusiewicz, Słownik biograficzny Wielkopolski Południowo-Wschodniej: ziemi kaliskiej, Kalisz 1998.

2 Jako przykład słowników biograficznych nauczycieli pracujących na określonym terenie można wymienić: J. Chrobaczyński (red.), Słownik biograficzny nauczycieli w Małopolsce w latach II wojny światowej (1939-1945): ofiary wojny, żotnierze, działacze konspiracyjni, nauczyciele w jawnym i tajnym szkolnictwie, Kraków 1995; J. Doroszewski (red.), Słownik biograficzny nauczycieli miasta Lublina w latach 1918-1939, Lublin 2007; J. Duda, A. Szelka, F. Dzionek (red.), Stownik biograficzny nauczycieli Ślaska Opolskiego, t. 1-6, Opole 1995; W. Prarat (red.), Stownik biograficzny nauczycieli szkót powszechnych gminy Gorzyce do I połowy XX wieku, Sandomierz 2007; A. Massalski (red.), Słownik biograficzny: nauczyciele szkót średnich rzqdowych męskich w Królestwie Polskim 1833-1862, Kielce 2007; A. Massalski, Stownik biograficzny zastużonych nauczycieli $i$ wychowanków: I Liceum Ogólnokształcqce im. Stefana Żeromskiego w Kielcach, Kielce 2010.
} 
ną Biblioteką Pedagogiczną w Koninie. Pracami Komitetu Redakcyjnego ${ }^{3}$ powołanego do powstania tej publikacji kierował Piotra Gołdyn ${ }^{4}$.

Dobór postaci zamieszczonych w publikacji, wynikał z propozycji zgłaszanych przez poszczególnych autorów, odpowiedzialnych za przygotowanie tej pracy. W ten sposób pojawiło się wiele różnych pomysłów, które wynikały nie tylko z czasu, w którym żyła opisywana postać czy miejsca pracy, ale także jej światopoglądu oraz pochodzenia społecznego. Ostatecznie zdecydowano, że w Słowniku zostaną zamieszczone informacje na temat tych osób, które miały znaczący wpływ na życie oświatowe na terenie Wielkopolski Wschodniej ${ }^{5}$. Przedstawiono biografie wychowawców, nauczycieli, pedagogów i bibliotekarzy pochodzących z tych terenów. Uwzględniono także inne osoby, które w różnym stopniu były związane z tym terenem, biorąc pod uwagę fakt urodzenia oraz ich zaangażowanie w pracę na rzecz oświaty. Znaczna część osób, których biografie zostały zamieszczone w publikacji urodziła się w XIX w. bądź w XX w.

W Słowniku zamieszczono sto biogramów według kolejności alfabetycznej. Nad ich przygotowaniem pracowało ponad trzystu autorów. Wśród nich należy wymienić m.in. takie nazwiska, jak: Piotr Gołdyn, Maciej Grzeszczak, Kazimierz Kasperkiewicz, Łukasz Parus czy Bogumiła Sawicka. Przy opracowywaniu tej publikacji nawiązano współpracę z historykami i regionalistami, a zwłaszcza nauczycielami, którzy pracowali w danym środowisku i posiadali informacje niezbędne do przygotowania tej publikacji. W Słowni$k u$ nie przyjęto jednorodnej formy biogramów, lecz uwzględniono najważniejsze kwestie, związane przede wszystkim z działalnością oświatową poszczególnych osób. Niektóre biogramy zawierają wyłącznie najważniejsze wiadomości na temat ich życia. Jednakże pojawiają się także opisy nacechowane emocjonalnie, zwłaszcza w tych biogramach, które zostały napisane przez członków rodziny. Redaktor Piotr Gołdyn we „Wstępie” zaznaczył, że ,zarówno autorzy, jak i redaktorzy »Słownika« nie zawsze mieli możliwość dotarcia do wszystkich istotnych faktów. Stąd mogą pojawić się pewne nieścisłości czy rozbieżności, a czasem jakieś pominięcia"6.

Podstawą źródłową dla opracowania Słownika były informacje pochodzące z akt osobowych, znajdujących się w archiwach poszczególnych szkół, urzędów gmin czy ar-

\footnotetext{
${ }^{3}$ W skład Komitetu Redakcyjnego Słownika weszli: Zbigniew Budny, Elwira Jeglińska, Jolanta Kmieć, Aleksandra Czajkowska i Wioletta Poturała. Jego celem było opracowanie zasad przygotowywania poszczególnych biogramów.

${ }^{4}$ Piotr Gołdyn urodził się w 1973 r. W 1999 r. ukończył teologię na Papieskim Wydziale Teologicznym w Warszawie. Trzy lata później uzyskał stopień doktora nauk humanistycznych z zakresu historii na Wydziale Humanistycznym Uniwersytetu Zielonogórskiego. Obecnie pełni funkcję dyrektora Ośrodka Doskonalenia Nauczycieli w Koninie. Jest także przewodniczącym Rady Redakcyjnej Konińskiego „Kuriera Oświatowego”. Jest autorem prac naukowych i popularnonaukowych. Dotychczas ukazały się jego następujące publikacje: Samorzad terytorialny $w$ Polsce na przełomie XX $i$ XXI wieku: I regionalna konferencja naukowa (2005); Symbolika religijna i kościelna w herbach miast polskich do końca XX wieku (2008); Z pól do wolności: szkic do dziejów opozycji wiejskiej na ziemi konińskiej (1980-1989), (2009); Trud i chwała strażaka: dzieje Ochotniczej Straży Pożarnej w Lqdku w latach 1908-2008, (2009); Protestantyzm w Polsce na przestrzeni wieków (2009); Religia w procesie resocjalizacji (2010); „Samorzqdna Rzeczpospolita: zarys dziejów i działalności Komitetów Obywatelskich »Solidarność« w regionie konińskim (1989-1991) (2011).

${ }^{5}$ Obecnie teren Wielkopolski Wschodniej obejmuje powiat kolski, koniński, słupecki i turecki.

${ }^{6}$ Stownik biograficzny nauczycieli Wielkopolski Wschodniej, red. P. Gołdyn, t. I, Konin 2012, s. 5.
} 
chiwów rodzinnych. Wśród nich należy wymienić Archiwum Zakładowe PWSZ w Koninie, Akta osobowe nauczycieli Zespołu Szkół Rolniczego Centrum Kształcenia Ustawicznego w Kościelcu, Dokumenty archiwalne Komendy Hufca ZHP w Kole, Archiwum Zakładowe Urzędu Gminy Wierzbinek, Archiwum Szkoły Podstawowej w Sławsku, a także w archiwach zagranicznych, m.in. Salezjańskie Archiwum Generalne w Rzymie. Przygotowując biogramy poszczególnych nauczycieli, oprócz danych archiwalnych, wiele informacji zaczerpnięto z lokalnej prasy, m.in. był to: „Przegląd Kolski”, „Głos Koła”, „Słowo Powszechne”, „Ziemia Kolska”, „Przegląd Koniński”, „Koniniana”, „Koniński Kurier Oświatowy”, „Gazeta Kleczewska”, jak i tej o charakterze ogólnopolskim „Gazeta Wyborcza”, „Rzeczpospolita”, „Nasz dziennik”. Przy opracowywaniu Słownika powołano się także na informacje zawarte w słownikach, w tym przede wszystkim Polskim słowniku biograficznym i pracy Biogramy uczonych polskich: materiały o życiu $i$ działalności członków AU w Krakowie, TNW, PAU, PAN. Autorzy Słownika wiedzę czerpali także z lokalnych kronik, takich jak: Kronika Gminy Władysławów, Kronika ZNP we Władysławowie Kronika Wojewódzkiej Biblioteki Pedagogicznej w Koninie za lata 1975-1999, czy kroniki szkolne. Szczególnie cenne były księgi pamiątkowe, będące w posiadaniu członków rodzin. W przygotowaniu biogramów wartościowe okazały się także następujące publikacje: Szkoły rolnicze w Kościelcu w latach 1920-1921, Zastużeni działacze Zwiazku Nauczycielstwa Polskiego województwa konińskiego 1905-1997, Szkoła zawodowa $w$ Kole i powiecie kolskim, Szkolnictwo średnie ogólnokształcace w Turku w okresie międzywojennym, Jubileusz Liceum Ogólnokształcacego im. Kazimierza Wielkiego w Kole.

Dzięki lekturze publikacji Słownik biograficzny nauczycieli Wielkopolski Wschodniej możemy poznać różnorodne „drogi” realizacji powołania nauczycielskiego. Należy również zaznaczyć, że przedstawieni w publikacji nauczyciele oprócz wykonywania zawodu w różnych typach szkół i na różnych szczeblach, zazwyczaj pełnili wiele innych funkcji w społeczeństwie. Wśród nich należy wymienić zarówno tych należących do określonych partii politycznych, jak i działaczy związkowych, samorządowych, duchownych, a także animatorów życia kulturalnego i społecznego. Posiadali oni szerokie zainteresowania i wiedzę z zakresu sztuki, literatury czy sportu. Tak szeroki zasób wiadomości z wielu dyscyplin naukowych, mógł przyczynić się do efektywniejszego wykonywania zawodu oraz aktywności w życiu społecznym. Warto podać przykłady wybitnych nauczycieli, którzy odegrali także ważną rolę w życiu naukowym i społeczno-oświatowym. Uosobieniem takiego nauczyciela jest postać wybitnego polskiego anatoma, wykładowcy akademickiego, trzykrotnego rektora Uniwersytetu Jagiellońskiego - Kazimierza Kostaneckiego (1863-1940). Studia ukończył na Uniwersytecie w Berlinie. Głównym przedmiotem jego zainteresowań była anatomia człowieka. Założył w Polsce największą krakowską szkołę anatomiczną i anatomoporównawczą. W ten sposób przyczynił się do rozwoju polskiej nauki, prowadząc nowoczesne badania w tym zakresie, a także czynnie angażując się w prace wielu towarzystw naukowych polskich i zagranicznych. W pamięci potomnych zachował się jako „wspaniały mówca i wykładowca, niezrównany mistrz 
języka polskiego, niemieckiego i francuskiego"7. Tytułem przykładu można także odnotować postać Bolesława Józefa Kubiaka (1911-1997), który realizował się nie tylko w zawodzie nauczyciela, ale także w pracy społecznej. Przed II wojną światową pracował jako dziennikarz w Inowrocławiu. W lokalnej prasie ukazało się kilkanaście jego młodzieńczych utworów poetyckich. Jako członek Stronnictwa Narodowego angażował się w życie polityczne. Po wojnie został zatrudniony jako nauczyciel języka polskiego i angielskiego w szkole średniej w Kole. Największą satysfakcją zawodową dla Kubiaka było napisanie kilku podręczników do nauczania języka angielskiego. Jak podkreślił autor jego biogramu „od najmłodszych lat wyróżniał się wrażliwością, rozległymi zainteresowaniami i uporem w zdobywaniu wiedzy". Zasłużoną osobą dla Wielkopolski Wschodniej był także Ireneusz Ludwik Pawlak (1930-1986), polski ksiądz katolicki, katecheta i duszpasterz młodzieży. W młodości należał do drużyny harcerskiej. Po II wojnie światowej wstąpił do Niższego Seminarium Duchownego, następnie studiował w Wyższym Seminarium Duchownym we Włocławku, uzyskując w 1954 r. święcenia kapłańskie. Warto zaznaczyć, że od początku praca z młodzieżą była dla niego najważniejsza. Swoje powołanie duszpasterskie realizował przez „towarzyszenie młodzieży”, tzn. bywał w domach swoich uczniów, organizował dla nich pielgrzymki do sanktuariów maryjnych i innych miejsc świętych, prowadził rekolekcje oraz wyjeżdżał z młodymi ludźmi na obozy wędrowne. Należy podkreślić, że „był to kapłan i katecheta, którego życie i działalność wywarły wielki wpływ na decyzje, postawy, pracę i życie wielu młodych ludzi"9.

Przywołane biogramy trzech osób - Kazimierza Kostaneckiego, Bolesława Józefa Kubiaka i Ireneusza Ludwika Pawlaka - stanowią odzwierciedlenie szerokiego zainteresowania i czynnego zaangażowania w polskie szkolnictwo, jak i działania na rzecz społeczności lokalnej, wielu osób z Wielkopolski Wschodniej.

W sumie Słownik, ze względu na walory poznawcze, stanowi ważną publikację z zakresu pedeutologii historycznej. Mogą z niego korzystać nie tylko profesjonalni badacze historii oświaty i wychowania, ale i studenci i uczniowie, którzy chcą poznać zasługi osób decydujących o obliczu polskiej oświaty, kultury i nauki. Redakcja przygotowuje kolejne tomy tej publikacji.

Dorota Grabowska

\footnotetext{
7 Ibidem, s. 113.

8 Ibidem, s. 134.

9 Ibidem, s. 204.
} 